Nig. J. Biotech. Vol. 38 (1) : 120-131 (June 2021)

ISSN: 01891731

Available online at

http://www.ajol.info/index.php/njb/index

and www.biotechsocietynigeria.org

DOI: https://dx.doi.org/10.4314/njb.v38i1.14

\title{
Organoleptic properties and shelf-lives of differently dried fowl eggs
}

\author{
Idahor, K. 0. \\ Department of Animal Science, Nasarawa State University, Keffi, Shabu-Lafia Campus, P.M.B. 135, \\ Lafia, 950101, Nigeria
}

\begin{abstract}
Poultry eggs are perishable, hence could lose their quality rapidly between storage and consumption. Maintaining fresh quality is a major problem which is aggravated by temperature, humidity, storage method and time. Several methods of altering these environmental conditions to prolong the shelf-life of the eggs have been reported, yet little is known about kiln, solar and oven methods of drying boiled fowl eggs. This study was targeted at creating awareness, evaluating the organoleptic properties and determining the shelf-life of kiln-, solar- and oven-dried fowl eggs, stored under different environmental conditions. A total of 160 Isa brown freshly laid eggs were obtained and weighed, and were divided into four different groups of 40 eggs each, designated as control, kiln-, solar- and oven-dried. The eggs were boiled for $\mathbf{3 0}$ minutes and dried at $100-120^{\circ} \mathrm{C}$ overnight (kiln dried), $45-50^{\circ} \mathrm{C}$ for 5 days (solar dried) and $100^{\circ} \mathrm{C}$ for 24 hours (oven dried), but those in the control group were not dried. Panelists were used in obtaining information on awareness of fowl eggs drying/drying methods and organoleptic evaluation. Twenty-seven eggs each from the control, kiln-, solar- and ovendried groups were kept in locally fabricated egg packs and stored for $\mathbf{3 0}$ days in a sales outlet, deep freezer and kitchen for shelf-life determination. Results showed that egg weight loss was highest $(52.3 \%)$ in the kiln-dried, followed by oven-dried $(38.9 \%)$, solar-dried (27.4\%) and control $(20.6 \%)$ groups. All the panelists $(100 \%)$ were aware of the different forms of storing boiled fowl eggs and have eaten fowl eggs in different forms, but none $(0.0 \%)$ was aware of kiln, solar and oven method of drying fowl eggs, or has eaten kiln-, solar- and oven-dried fowl eggs before then. Some of the panelists liked the appearance, taste, aroma, mouth feel, after-taste and overall acceptability of the dried eggs. All (100\%) of the eggs in the sales outlet spoilt, but none $(0.0 \%)$ among the dried eggs stored in the deep freezer was spoilt. In the kitchen, all the control eggs $(100 \%), 22.2 \%$ (kiln dried), $88.9 \%$ (solar dried) and $66.7 \%$ (oven dried) spoilt. Kilnand oven-dried eggs had more water loss, apparently implying better effectiveness of the drying methods. Therefore, fowl eggs could be boiled, dried and refrigerated to elongate their shelf-lives.
\end{abstract}

Keywords: Biological value, egg preservation, egg pack, egg weight, smoked eggs.

Authors E-mail address: koidahor@nsuk.edu.ng

\section{Introduction}

Poultry eggs are believed to be the most multipurpose and near perfect foods in nature, due to the rich protein quality, essential amino acids, vitamins and minerals. The yolk and white components are both of high biological value and are highly digestible hence, its vital culinary roles in different dishes (IsoNova,
2016; Ndife et al., 2010; Hoffman and Falvo, 2004). According to Hussein et al. (1996), the quality of nutrients present in poultry eggs, can hardly be found in any other foodstuff. More significantly, poultry eggs are known to supply the best proteins besides milk (IsoNova, 2016; Vaclavik and Christian, 2008; Hoffman and Falvo, 2004). A range of 13 $16 \%$ crude protein, $1.34-1.56 \%$ ash, $10.3-$ 
$12.7 \%$ crude fat and gross energy of 1.8 $2.2 \mathrm{kcal} / 100 \mathrm{~g}$ have been reported in fowl raw and hard-boiled eggs (Idahor et al., 2017; Wikipedia 2016a, Wikipedia 2016b). Poultry eggs size or weight could be categorised as small $(45-49 \mathrm{~g})$, medium/large $(50-65 \mathrm{~g})$, extra-large $(65-69 \mathrm{~g})$ or jumbo $(70 \mathrm{~g}$ and above) according to egg sizing and grading propounded by USDA (2000; 2014).

Fresh eggs functional properties such as emulsification, thickening, foaming and moisturizing have contributed immensely to the required features and functions in the industrial production of many food products (Bueschelberger, 2004). Essentially, fresh albumen has been used in the production of edible packing films that could form water soluble packets, for ingredients in the food, chemical and pharmaceutical industries. It is a natural antioxidant that is added to ground meat to decrease oxidation during cooking. Also, it is used as a binder for pigments, waterproof glue and varnish (Froning, 1998). Similarly, fresh egg yolk is a major source of fatty acids, minerals and vitamins. Many vaccines for infectious diseases are produced in poultry fertile eggs yolk. It is used in painting as a component of egg-tempera to make liqueurs and egg oil extraction. The extracted egg oil and lecithin from egg yolk are veritable materials used in biotechnology as well as food and pharmaceutical industries (Bueschelberger, 2004). More importantly, fresh egg yolk is used in the production of agar that is used in the identification of clostridia species in contaminants (King-ori, 2012).

Unfortunately, poultry fresh eggs are highly perishable in nature and difficult to transport due to their bulkiness and fragility, hence the adoption of dehydration technique to obtain egg powder that provides a near complete solution to the problem of perishability and transportation (Frazier and Westerhoff, 1988; Jay, 2000). However, it was speculated that if care is not taken, the technological procedures of egg powder production which involves washing, breaking, filtering and pasteurization of the fresh egg may introduce microbial contamination. Although several other processing and preservation methods like spray-drying, tray-drying and freeze-drying techniques have been reported, they are with attendant repercussions on the product qualities (Potter and Hotchkiss, 2006).

In Nigeria, poultry eggs production is one of the leading economic ventures undertaken by the small-scale farmers. But at the peak of production, there is always a glut that has resulted in the destruction of large quantities of table eggs, because of the relatively short shelf life. Consequently, table eggs are seasonal and as such not affordable during the off season hence, the need to explore possible strategies to increase fowl fresh eggs shelf life, in order to have table eggs at an affordable rate all-year round. There is little or no information on the awareness, consumption and organoleptic properties of fowl dried eggs. On this premise, fowl eggs were kiln dried, solar dried as well as oven dried and some of them were processed for organoleptic evaluation and others were kept in fabricated egg packs and stored in sales outlet, deep freezer and kitchen for shelf life determination.

\section{Materials and methods}

\section{Climatic condition of the experimental site}

The experiment was conducted at the Livestock Research and Demonstration Farm, Faculty of Agriculture, Nasarawa State University, Keffi, Shabu-Lafia Campus, located on latitude $08^{\circ} 35^{\prime} \mathrm{N}$ and longitude $08^{\circ} 33^{\prime} \mathrm{E}$ in the Guinea savannah zone of north central Nigeria. Lafia has an altitude of $181 \mathrm{~m}$ above sea level, temperature ranging from 32 to $35^{\circ} \mathrm{C}$, relative humidity between 58 and $63 \%$, average daylight of 9 to 12 hours and approximately $1,400 \mathrm{~mm}$ rainfall per annum (NIMET, 2011).

\section{Egg pack fabrication}

The egg packs were fabricated using metal pan, foam and aluminium foil. They were designed such that it has 3 trays held in an egg-shape frame, to be inserted in a cylindrical container with a lid to ensure airtight condition (see plate 1). 


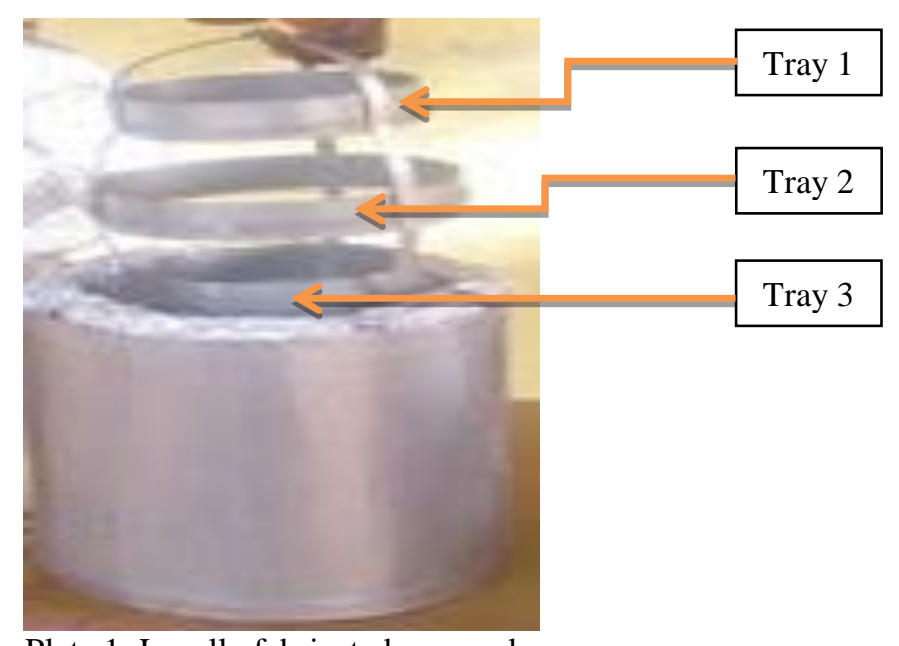

Plate 1: Locally fabricated egg pack

\section{Experimental design}

A total of one hundred and sixty Isa brown freshly laid eggs (within 13 hours of lay) were obtained, weighed using a sensitive weighing

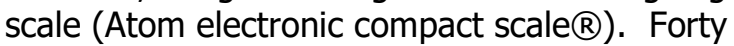
eggs each were assigned to the treatments based on weight in a completely randomised design. The treatments were designated as control, kiln dried eggs, solar dried eggs and oven dried eggs.
Plate 2: Boiling of fowl eggs with inserted thermometer probe

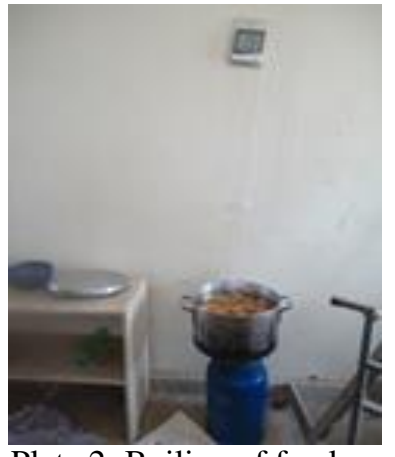

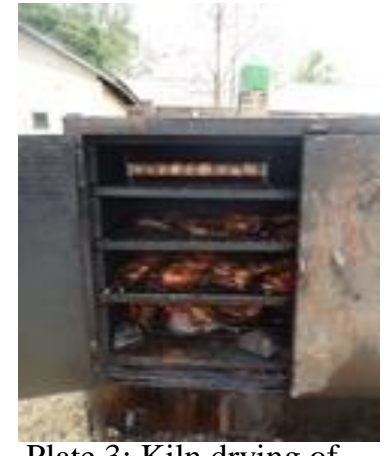

Plate 3: Kiln drying of fowl eggs

\section{Awareness, consumption and organoleptic evaluation of the experimental eggs}

Twenty trained taste panelists encompassing male and female students, security personnel, academic and non-academic staff, were sourced within Nasarawa State University, Keffi, Shabu-Lafia Campus. Structured questionnaires were designed and
Drying of the experimental eggs

All the experimental eggs were boiled for 30 minutes, weighed immediately, reweighed after cooling and 27 eggs each were dried at $100-120^{\circ} \mathrm{C}$ overnight (kiln), $45-50^{\circ} \mathrm{C}$ for 5 days (solar) and $100^{\circ} \mathrm{C}$ for 24 hours (oven) (see plates $2-5$ ) and reweighed after drying. The 27 eggs in control were however not dried.

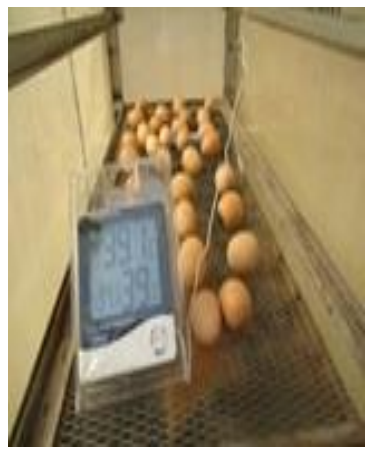

Plate 4: Solar drying of fowl eggs

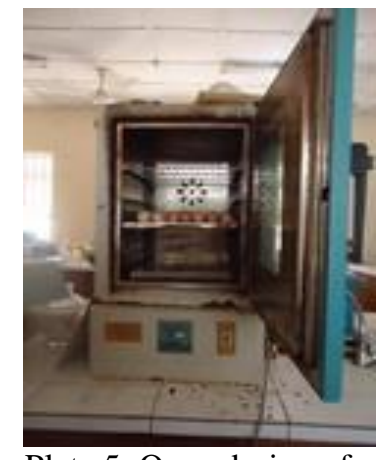

Plate 5: Oven drying of fowl eggs administered to the panelists, to know if they were familiar with fowl egg drying. A total of 13 eggs per control, kiln dried, solar dried and oven dried treatments summing up to 52 eggs were processed and offered to the trained panelists for organoleptic quality evaluation (see plates $6-9$ ) following the procedure of Wichchukit and O'Mahony (2014). 


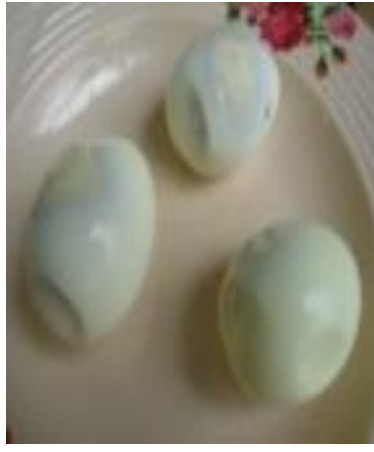

Plate 6: Boiled fowl eggs

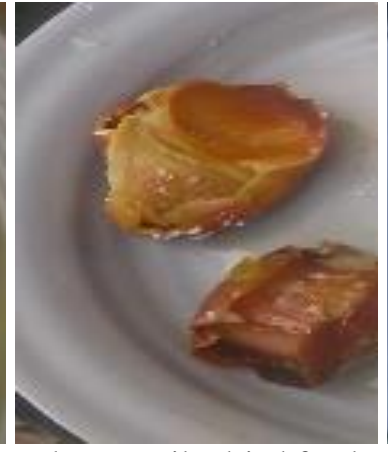

Plate 7: Kiln dried fowl eggs

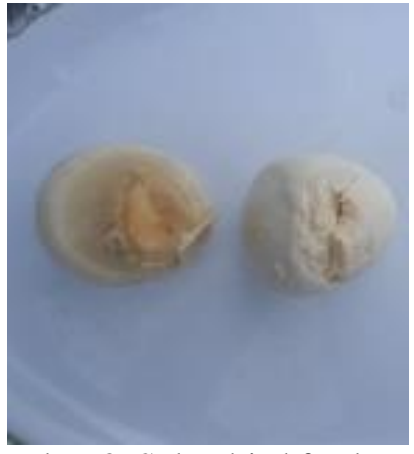

Plate 8: Solar dried fowl eggs

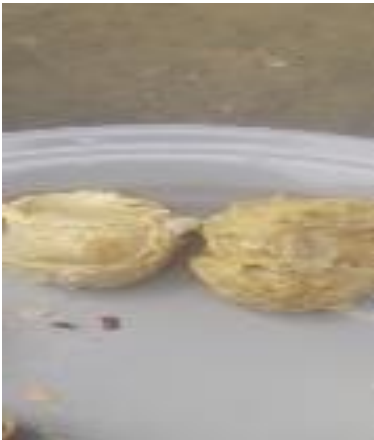

Plate 9: Oven dried fowl eggs

Storage of the experimental eggs

All the kiln, solar and oven dried eggs as well as control eggs were stored in the locally fabricated egg packs (see plates 10 and 11). Such that 3 eggs each of control, kiln, solar

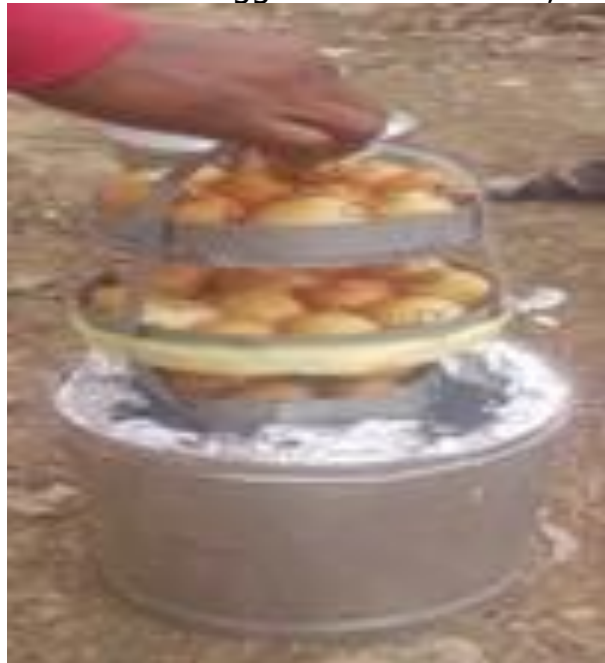

Plate 10: Experimental eggs in fabricated egg pack and oven dried were arranged on each of the 3 trays in the fabricated egg packs kept in a sales outlet, deep freezer and kitchen cabinet/chamber for a storage period of 30 days.

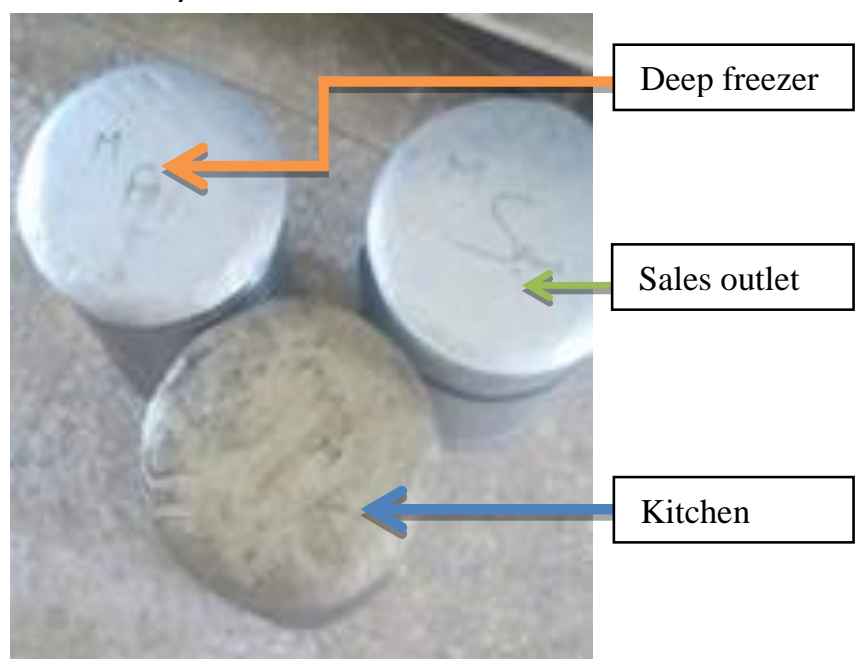

Plate 11: Fabricated egg packs containing stored eggs
At the end of the experiment, all the fabricated egg packs with the experimental eggs were brought to the laboratory and all the experimental eggs were carefully opened to check for spoilage. Those with intact albumen and yolk were termed "good eggs", those with mild odour, little discolouration and disintegrated albumen and yolk but could be consumed were referred to as "deteriorated eggs" while those with offensive rotten egg odour, extensive discolouration and disintegration of the albumen and yolk were called "spoilt eggs" (see plates 12 - 14). 


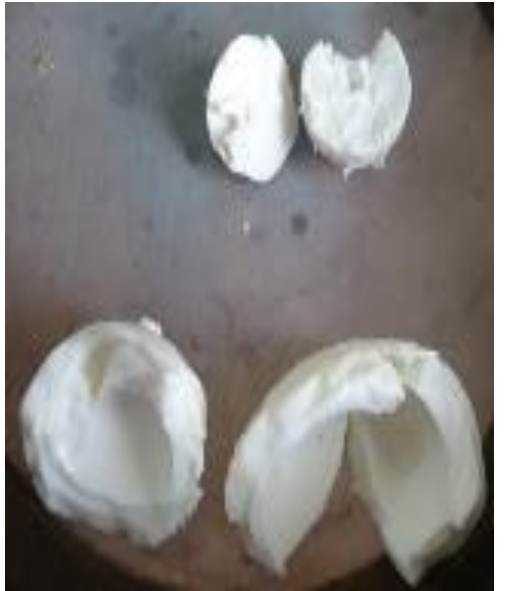

Plate 12: Good egg

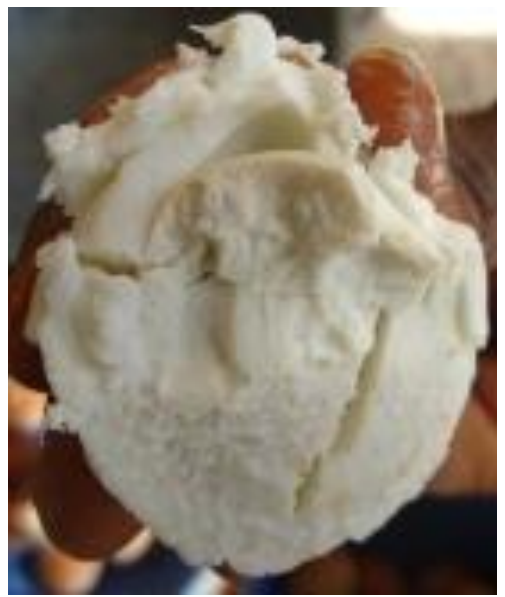

Plate 13: Deteriorated egg

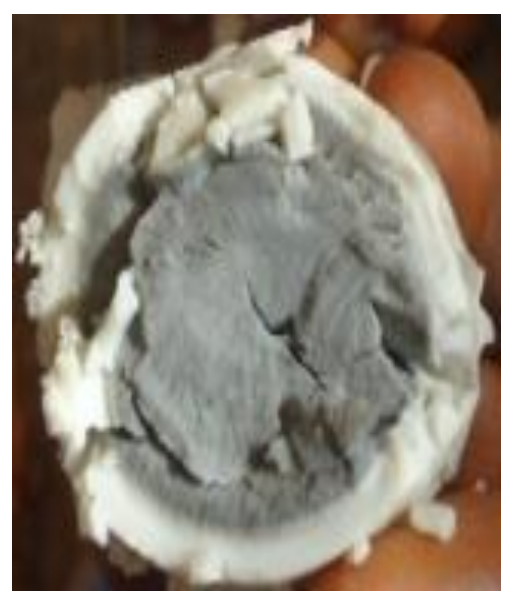

Plate 14: Spoilt egg
Data collection and statistical analysis

The differences between the initial egg weight and warm egg weight, cool egg weight and final egg weight represented egg weight loss and the percentage final egg weight loss was determined using equation 1 as given by Suresh et al. (2015).

Eggwejghtloss $(\%)=\frac{\text { Initial egg wejght }- \text { final egg wejght after drying }}{\text { Initial egg weight }} \times \frac{100}{1}$ „.. equation 1

The panelists were offered fowl eggs in different forms during training for familiarisation prior to data collection. Their responses in the structured questionnaires represented their opinions and were presented in values as well as percentages of occurrence. The organoleptic properties of the experimental eggs were evaluated using a nine-point Hedonic scale according to Wichchukit and O' Mohany (2014). The temperature during egg drying and storage was determined using thermometers with sensitive probes and was recorded in the morning, afternoon and evening on a daily basis. However, the temperature in the deep freezer was not determined because it was within sub-zero. Where applicable, the data collected were subjected to simple descriptive statistics and analysis of variance procedure with means separation adopting Duncan Multiple Range Test at $5 \%$ probability using software package of SPSS (2010).

\section{Results}

Table 1 shows the effects of boiling and drying on fowl eggs weight. There were significant differences $(P>0.05)$ in all the parameters measured except, initial egg weight and warm egg weight that varied from $54.07-55.96 \mathrm{~g}$ and $51.48-54.48 \mathrm{~g}$ respectively. While the cool egg weight ranged from $51.23-54.05 \mathrm{~g}$, the final egg weight was highest $(44.66 \mathrm{~g})$ in control, followed by solar dried eggs (39.74g), oven dried eggs $(34.75 \mathrm{~g})$ and kiln dried eggs $(26.43 \mathrm{~g})$, in that order. Conversely, the percentage of egg weight loss was highest $(52.34 \%)$ in kiln dried eggs, $38.88 \%$ in oven dried eggs, $27.42 \%$ in solar dried egg and lowest $(20.59 \%)$ in control.

Table 1: Effects of boiling and drying on fowl eggs weight

\begin{tabular}{|c|c|c|c|c|c|}
\hline \multirow[b]{2}{*}{ Parameters } & \multicolumn{5}{|c|}{ Treatments ( \pm STD) } \\
\hline & Control & Kiln dried & Solar dried & Oven dried & P-value \\
\hline No. of eggs & 40 & 40 & 40 & 40 & - \\
\hline Initial egg weight (g) & $55.96 \pm 7.30$ & $54.07 \pm 8.22$ & $54.72 \pm 5.59$ & $54.53 \pm 3.61$ & 0.934 \\
\hline Warm egg weight (g) & $54.48 \pm 7.06$ & $52.80 \pm 7.86$ & $53.07 \pm 5.44$ & $51.48 \pm 4.76$ & 0.804 \\
\hline Warm egg weight loss (g) & $1.48 \pm 0.32^{b}$ & $1.27 \pm 0.44^{b}$ & $1.65 \pm 0.37^{b}$ & $3.04 \pm 1.51^{\mathrm{a}}$ & 0.000 \\
\hline Cool egg weight (g) & $54.05 \pm 7.02$ & $52.06 \pm 7.36$ & $52.77 \pm 5.36$ & $51.23 \pm 4.86$ & 0.804 \\
\hline Cool egg weight loss (g) & $1.91 \pm 0.40^{\mathrm{b}}$ & $2.01 \pm 1.67^{b}$ & $1.94 \pm 0.50^{\mathrm{b}}$ & $3.30 \pm 1.64^{\mathrm{a}}$ & 0.058 \\
\hline Final egg weight $(\mathrm{g})$ & $44.66 \pm 8.26^{a}$ & $26.43 \pm 5.73^{c}$ & $39.74 \pm 5.44^{\mathrm{ab}}$ & $34.75 \pm 7.40^{\mathrm{b}}$ & 0.000 \\
\hline Final egg weight loss (g) & $11.30 \pm 6.82^{c}$ & $27.64 \pm 6.03^{a}$ & $14.96 \pm 8.30^{\mathrm{bc}}$ & $19.77 \pm 6.17^{b}$ & 0.000 \\
\hline Percentage final egg weight loss & $20.59 \pm 12.08^{c}$ & $52.34 \pm 7.59^{a}$ & $27.42 \pm 12.88^{c}$ & $38.88 \pm 13.26^{b}$ & 0.000 \\
\hline
\end{tabular}

STD: Standard deviation 
Expressed in figure 1 is the panelists' awareness of drying and consumption of fowl eggs. It was shown that all the panelists $(100 \%)$, claimed to be aware of different forms of storing boiled fowl eggs and have eaten fowl eggs in different forms. Yet, none of them $(0.0 \%)$ was neither aware of kiln, solar and oven drying of fowl eggs, nor has eaten kiln, solar and oven dried fowl eggs before now.

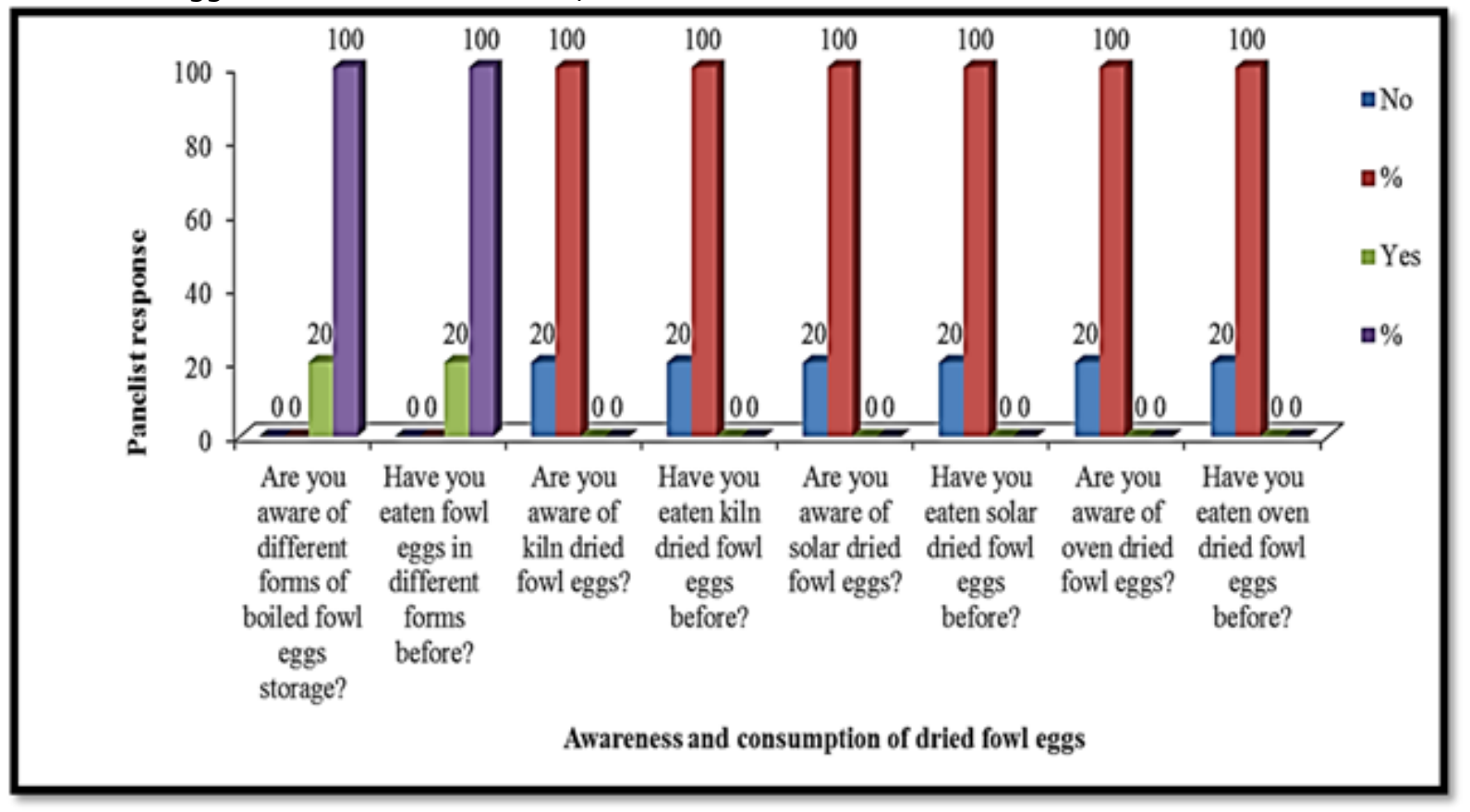

Figure 1: Panellists awareness of drying and consumption of fowl eggs

Table 2: Effects of boiling and drying on appearance, taste, colour and aroma of fowl eggs

\begin{tabular}{l|l|l|l|l|l}
\hline \multirow{3}{*}{ Parameters } & & \multicolumn{4}{c}{ Treatments } \\
\cline { 2 - 6 } & Hedonic scale & Control & Kiln dried & Solar dried & Oven dried \\
\hline \multirow{5}{*}{ Appearance } & Disliked extremely & $0(0.0)$ & $3(15.0)$ & $1(5.0)$ & $1(5.0)$ \\
& Disliked very much & $3(15.0)$ & $2(10.0)$ & $1(5.0)$ & $1(5.0)$ \\
& Disliked moderately & $1(5.0)$ & $1(5.0)$ & $1(5.0)$ & $1(5.0)$ \\
& Disliked slightly & $3(15.0)$ & $3(15.0)$ & $1(5.0)$ & $2(10.0)$ \\
& Neither liked nor disliked & $1(5.0)$ & $1(5.0)$ & $1(5.0)$ & $2(10.0)$ \\
& Liked slightly & $2(10.0)$ & $4(20.0)$ & $4(20.0)$ & $4(20.0)$ \\
& Liked moderately & $2(10.0)$ & $2(10.0)$ & $4(20.0)$ & $1(5.0)$ \\
& Liked very much & $5(25.0)$ & $2(10.0)$ & $4(20.0)$ & $4(20.0)$ \\
\multirow{5}{*}{ Taste } & Liked extremely & $3(15.0)$ & $2(10.0)$ & $3(15.0)$ & $4(20.0)$ \\
& Disliked extremely & $0(0.0)$ & $2(10.0)$ & $0(0.0)$ & $0(0.0)$ \\
& Disliked very much & $1(5.0)$ & $2(10.0)$ & $1(5.0)$ & $1(5.0)$ \\
& Disliked moderately & $0(0.0)$ & $3(15.0)$ & $1(5.0)$ & $1(5.0)$ \\
& Disliked slightly & $1(5.0)$ & $2(20.0)$ & $2(10.0)$ & $3(15.0)$ \\
& Neither liked nor disliked & $1(5.0)$ & $1(5.0)$ & $2(10.0)$ & $3(15.0)$ \\
& Liked slightly & $2(10.0)$ & $4(20.0)$ & $4(20.0)$ & $1(5.0)$ \\
& Liked moderately & $5(25.0)$ & $4(20.0)$ & $4(20.0)$ & $5(25.0)$ \\
& Liked very much & $5(25.0)$ & $1(5.0)$ & $4(20.0)$ & $4(20.0)$ \\
& Liked extremely & $5(25.0)$ & $1(5.0)$ & $2(10.0)$ & $2(10.0)$ \\
& Disliked extremely & $0(0.0)$ & $4(20.0)$ & $0(0.0)$ & $1(5.0)$ \\
& Disliked very much & $0(0.0)$ & $1(5.0)$ & $1(5.0)$ & $1(5.0)$ \\
& Disliked moderately & $2(10.0)$ & $1(5.0)$ & $1(5.0)$ & $1(5.0)$ \\
& Disliked slightly & $1(5.0)$ & $1(5.0)$ & $1(5.0)$ & $3(15.0)$ \\
& Neither liked nor disliked & $3(15.0)$ & $1(5.0)$ & $1(5.0)$ & $1(5.0)$
\end{tabular}




\begin{tabular}{llllll} 
& Liked slightly & $2(10.0)$ & $4(20.0)$ & $6(30.0)$ & $4(20.0)$ \\
& Liked moderately & $4(20.0)$ & $3(15.0)$ & $3(15.0)$ & $4(20.0)$ \\
& Liked very much & $4(20.0)$ & $3(15.0)$ & $4(20.0)$ & $4(20.0)$ \\
& Liked extremely & $4(20.0)$ & $2(10.0)$ & $3(15.0)$ & $1(5.0)$ \\
& Disliked extremely & $1(5.0)$ & $2(10.0)$ & $1(5.0)$ & $1(5.0)$ \\
& Disliked very much & $1(5.0)$ & $2(10.0)$ & $0(0.0)$ & $1(5.0)$ \\
& Disliked moderately & $0(0.0)$ & $1(5.0)$ & $1(5.0)$ & $2(10.0)$ \\
& Disliked slightly & $1(5.0)$ & $2(10.0)$ & $2(10.0)$ & $3(15.0)$ \\
& Neither liked nor disliked & $1(5.0)$ & $3(15.0)$ & $1(5.0)$ & $1(5.0)$ \\
& Liked slightly & $2(10.0)$ & $4(20.0)$ & $5(25.0)$ & $6(30.0)$ \\
& Liked moderately & $4(20.0)$ & $2(10.0)$ & $4(20.0)$ & $2(10.0)$ \\
& Liked very much & $7(35.0)$ & $1(5.0)$ & $4(20.0)$ & $2(10.0)$ \\
\hline
\end{tabular}

Values in parenthesis represent percentage (\%) of occurrence and are purely the responses of the panelists; Control: Boiled fowl eggs without drying

Effects of boiling and drying on fowl eggs' appearance, taste, colour and aroma are given in table 2. It was observed that none of the panelists $(0.0 \%)$ disliked the appearance of the boiled fowl eggs extremely in the control (i.e. without drying). Whereas, $3(15.0 \%)$ of them disliked extremely the appearance of the kiln dried eggs and 1 (5.0\%) each disliked extremely the appearance of solar and oven dried fowl eggs. While 1 panelist (5.0\%) neither liked nor disliked the appearance of the control, kiln and solar dried fowl eggs, 4 $(20.0 \%) 3(15.0 \%)$ and $2(10.0 \%)$ liked extremely the appearance of oven, control, solar and kiln dried fowl eggs, accordingly.

None of the panelists disliked the taste of all the eggs extremely, except 2 representing $10.0 \%$. While 3 panelists (15.0\%) neither liked nor disliked the oven dried egg taste, 2 panelists (10.0\%) neither liked nor disliked solar dried eggs and 1 (5.0\%) each neither liked nor disliked control and kiln dried egg taste. Five panelists $(25.0 \%)$ liked extremely the control eggs taste, $2(10.0 \%)$ each liked extremely the taste of solar and oven dried eggs whereas, $1(5.0 \%)$ liked extremely the taste of kiln dried eggs.

While no panelist $(0.0 \%)$ disliked extremely the colour of the control and solar dried eggs, $4(20.0 \%)$ of them disliked extremely the colour of kiln dried eggs and $1(5.0 \%)$ disliked extremely the colour of oven dried eggs. Three of the panelists $(15.0 \%)$ neither liked nor disliked the colour of control eggs, 1 (5.0\%) neither liked nor disliked the colour of the dried eggs. The control eggs colour as well as solar, kiln and oven dried eggs colour were liked extremely by $4(20.0 \%), 3(15 \%), 2$ $(10.0 \%)$ and $1(5.0 \%)$ panelists in that order. The aroma of kiln dried eggs was disliked extremely by $2(10.0 \%)$ panelists and 1 (5.0\%) each disliked extremely the aroma of control eggs, solar and oven dried eggs. Three panelists $(15.0 \%)$ neither liked nor disliked the aroma of kiln dried eggs and 1 (5.0\%) each neither liked nor disliked the aroma of control eggs, solar and oven dried eggs. While 3 panelists $(15.0 \%)$ each liked extremely the aroma of control eggs and kiln dried eggs, 2 $(10.0 \%)$ each liked extremely the aroma of solar and oven dried eggs.

Shown in table 3 are the effects of boiling and drying on mouth feel, after taste and overall acceptability of fowl eggs. It was shown that no panelist disliked the mouth feel of the control eggs except $1(5.0 \%)$ that disliked slightly whereas, a range of $1-3$ panelists disliked the dried eggs. While 2 panelists $(10.0 \%)$ neither liked nor disliked the mouth feel of the kiln dried eggs, 1 (5.0\%) each was recorded in control, solar and oven dried eggs. Five $(25.0 \%)$ of the panelists liked slightly the mouth feel of the kiln dried eggs, $4(20.0 \%)$ each of solar and oven dried eggs and 2 $(10.0 \%)$ recorded in control eggs.

Table 3: Effects of boiling and drying on mouth feel, after taste and over-all acceptability of fowl eggs

\begin{tabular}{|c|c|c|c|c|c|}
\hline \multirow[b]{2}{*}{ Parameters } & \multirow[b]{2}{*}{ Hedonic scale } & \multicolumn{4}{|c|}{ Treatments } \\
\hline & & Control & Kiln dried & Solar dried & Oven dried \\
\hline \multirow{3}{*}{ Mouth feel } & Disliked extremely & $0(0.0)$ & $3(15.0)$ & $1(5.0)$ & $1(5.0)$ \\
\hline & Disliked very much & $0(0.0)$ & $1(5.0)$ & $1(5.0)$ & $1(5.0)$ \\
\hline & Disliked moderately & $0(0.0)$ & $1(5.0)$ & $1(5.0)$ & $1(5.0)$ \\
\hline
\end{tabular}


Idahor ./ Nig. J. Biotech. Vol. 38 Num. 1 : 120-131 (June 2021)

\begin{tabular}{llllll} 
& Disliked slightly & $1(5.0)$ & $1(5.0)$ & $2(10.0)$ & $3(15.0)$ \\
& Neither liked nor disliked & $1(5.0)$ & $2(10.0)$ & $1(5.0)$ & $1(5.0)$ \\
& Liked slightly & $2(10.0)$ & $5(25.0)$ & $4(20.0)$ & $4(20.0)$ \\
& Liked moderately & $4(20.0)$ & $2(10.0)$ & $4(20.0)$ & $2(10.0)$ \\
& Liked very much & $5(25.0)$ & $3(15.0)$ & $5(25.0)$ & $5(25.0)$ \\
& Liked extremely & $7(35.0)$ & $2(10.0)$ & $2(10.0)$ & $2(10.0)$ \\
& Disliked extremely & $0(0.0)$ & $2(10.0)$ & $1(5.0)$ & $0(0.0)$ \\
& Disliked very much & $1(5.0)$ & $2(10.0)$ & $1(5.0)$ & $1(5.0)$ \\
After taste & Disliked moderately & $0(0.0)$ & $1(5.0)$ & $1(5.0)$ & $2(10.0)$ \\
& Disliked slightly & $1(5.0)$ & $2(10.0)$ & $1(5.0)$ & $2(10.0)$ \\
& Neither liked nor disliked & $1(5.0)$ & $2(10.0)$ & $1(5.0)$ & $1(5.0)$ \\
& Liked slightly & $1(5.0)$ & $2(10.0)$ & $6(30.0)$ & $3(15.0)$ \\
& Liked moderately & $5(25.0)$ & $4(20.0)$ & $3(15.0)$ & $5(25.0)$ \\
& Liked very much & $5(25.0)$ & $3(15.0)$ & $2(10.0)$ & $4(20.0)$ \\
& Liked extremely & $6(30.0)$ & $2(10.0)$ & $4(20.0)$ & $2(10.0)$ \\
& Disliked extremely & $1(5.0)$ & $2(10.0)$ & $1(5.0)$ & $1(5.0)$ \\
Over-all & Disliked very much & $1(5.0)$ & $1(5.0)$ & $1(5.0)$ & $1(5.0)$ \\
acceptability & Disliked moderately & $1(5.0)$ & $1(5.0)$ & $1(5.0)$ & $1(5.0)$ \\
& Disliked slightly & $1(5.0)$ & $2(10.0)$ & $1(5.0)$ & $1(5.0)$ \\
& Neither liked nor disliked & $1(5.0)$ & $2(10.0)$ & $2(10.0)$ & $1(5.0)$ \\
& Liked slightly & $1(5.0)$ & $2(10.0)$ & $4(20.0)$ & $5(25.0)$ \\
& Liked moderately & $3(15.0)$ & $4(20.0)$ & $2(10.0)$ & $3(15.0)$ \\
& Liked very much & $4(20.0)$ & $2(10.0)$ & $4(20.0)$ & $4(20.0)$ \\
& Liked extremely & $7(35.0)$ & $4(20.0)$ & $4(20.0)$ & $3(15.0)$ \\
\hline
\end{tabular}

Values in parenthesis represent percentage (\%) of occurrence and are purely the responses of the panelists; Control: Boiled fowl eggs without drying.

While 5 panelists (25.0\%) liked the mouth feel of the control eggs very much, solar and oven dried eggs, $3(15.0 \%)$ were recorded in the kiln dried eggs. Seven panelists (35.0\%) liked the mouth feel of the control eggs extremely and $2(10.0 \%)$ were recorded each in the dried eggs.

No panelist (\%) extremely disliked the after taste of the control and oven-dried eggs, but 2 $(10.0 \%)$ and $1(5.0 \%)$ penalists extremely disliked the after taste of the kiln and solar dried eggs, respectively. Two panelists $(10.0 \%)$ neither liked nor disliked the after taste of the kiln dried eggs, 1 (5.0\%) each was recorded in control, solar and oven dried eggs. Six panelists $(30.0 \%)$ slightly liked the after taste of the solar dried eggs, while 3 $(15.0 \%), 2(10.0 \%)$ and $1(5.0 \%)$ were recorded in the oven, kiln and control eggs in that order. Five panelists (25.0\%) moderately liked the after taste of the control and ovendried eggs, $4(20.0 \%)$ and $3(15.0 \%)$ were recorded in the kiln- and solar-dried eggs, accordingly. Majority of the panelists (30.0\%) extremely liked the after taste of the control eggs, followed by $20.0 \%$ (solar-dried eggs) and $10.0 \%$ each of kiln- and oven-dried eggs. However, a panelist each disliked the overall acceptability of all the experimental eggs very much and mof=derately, respectively, whereas $2(10.0 \%)$ neither liked nor disliked the kilnand solar-dried eggs, 4 (20.0\%) liked all the experimental eggs very much except the kilndried eggs $(10.0 \%)$. Majority of the panelists $(35.0 \%)$ extremely liked the overall acceptability of the control eggs compared to $4(20.0 \%)$ recorded in the kiln- and solar-dried eggs and $3(15.0 \%)$ in oven-dried eggs.

Table 4 provides the effects of different drying methods on the shelf life of the fowl eggs. It was observed that all the control eggs $(100.0 \%)$ stored in the sales outlet and kitchen were spoilt.

Among those stored in the deep freezer, only an egg $(11.1 \%)$ was spoilt, $2(22.2 \%)$ were good and $6(66.7 \%)$ deteriorated. All the kilndried eggs $(100.0 \%)$ stored at the sales outlet got spoilt; those stored in the deep freezer were all $(100.0 \%)$ good.

Table 4: Effects of different drying methods on shelf life of fowl boiled eggs

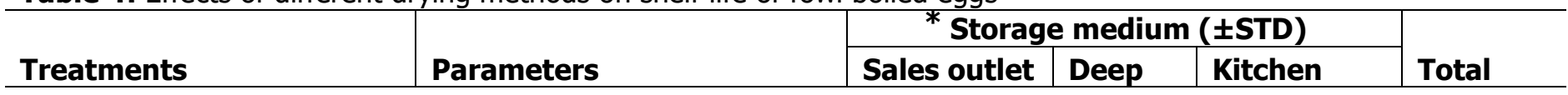




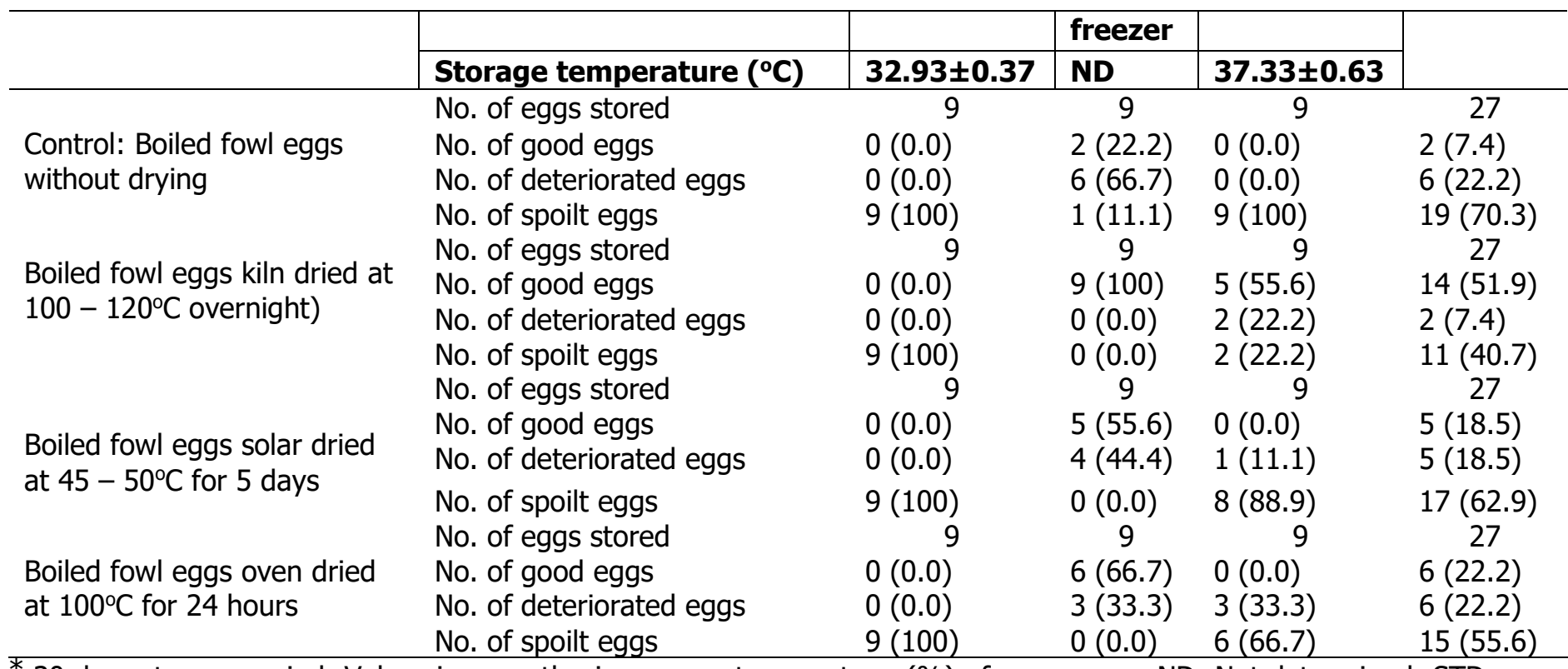

* 30 days storage period; Values in parenthesis represent percentage (\%) of occurrence; ND: Not determined; STD: Standard deviation

Among the kiln-dried eggs stored in the kitchen, $5(55.6 \%)$ were good, $2(22.2 \%)$ each were deteriorated and spoilt, respectively. None $(0.0 \%)$ of the solar-dried eggs stored in the deep freezer was spoilt; 5 $(55.6 \%)$ were good and $4(44.4 \%)$ were deteriorated. Eight $(88.9 \%)$ in the kitchen got spoilt and $1(11.1 \%)$ deteriorated, while all $(100.0 \%)$ the solar-dried eggs in the sales outlet were spoilt. Six $(66.7 \%)$ of the ovendried eggs stored in the deep freezer were good and 3 (33.3\%) deteriorated. All the eggs $(100.0 \%)$ in the sales outlet got spoilt, 3 $(33.3 \%)$ among those in the kitchen deteriorated and $6(66.7 \%)$ spoilt.

\section{Discussion}

The egg weight was similar to a range of $50-$ $65 \mathrm{~g}$ classified as medium/large by USDA (2014), thus the experimental eggs were perhaps normal and suitable for this study. It was observed that warm and cool temperatures influenced the egg weight, possibly due to the rate of warm or cool water loss from the boiled eggs. At the end of drying, egg weight loss was higher than a range of $0.16-5.4 \mathrm{~g}$ recorded in fowl eggs stored at room temperature (Addo et al. 2018; Khan et al. 2013; Jin et al. 2011; Dudusola, 2009). This could be largely due to the variations in fresh and dried eggs. However, the observed egg weight loss was less than a range of $88.4-99.2 \%$ weight loss reported in Half white (Embrapa White Leghorn CC strain) and Half brown strains' (Embrapa Rhode Island Red GG) fresh eggs, stored at room temperature and under refrigeration during the Summer and Autumn seasons (Feddern et al. 2017). The more weight loss observed in kiln dried and oven dried eggs possibly indicated more water loss hence, the likely concentration of nutrients in the dried eggs. Consequently, boiled fowl eggs could be dried to elongate the shelf life to enhance egg and egg-derived foods availability propounded by Miranda et al. (2015). Meanwhile, the similarity in percentage final egg weight loss recorded in the control and solar dried eggs perhaps, showed inefficiency of solar drier to remove adequate moisture desired in the principle of drying and storage.

The panelists' awareness of different forms of storing boiled fowl eggs and consumption of fowl eggs in different forms, probably expressed their familiarity with fowl eggs. However, none of them was aware of kiln, solar or oven drying of fowl eggs. The fear of hard boiled or smoked fowl eggs losing its nutritional quality may be allayed, as Idahor et al. (2017) reported no differences in the nutritional compositions of fowl eggs boiled for 10 minutes and 1 hour respectively. Meanwhile, the quality of fowl eggs once laid cannot be improved any further however its maintenance is possible though mostly a preventive process. Thus, quick collection and rapid storage in the cool room could minimize the quality problems (Zaheer, 2015). Therefore, this study may be a veritable 
means of creating awareness, on the possibility of boiling, drying and storing fowl eggs, to enhance availability all-year round in order to meet the maternal, children and the world's poor nutritional needs (Iannotti et al., 2014; Ruxton, 2013).

It was revealed that none of the panelists extremely disliked the appearance, taste and colour of the control eggs, probably due to their familiarity with boiled fowl eggs. The higher value of disliked extremely in kiln dried eggs' appearance, seemingly indicated their unfamiliarity with smoked boiled eggs thus, buttressing the low level of awareness among the panelists. Meanwhile, Raichlen (2010) defined smoked eggs as a type of "hors d'oeuvre" of hard boiled or uncooked eggs that are shelled, marinated and then smoked, that could be used to enhance the flavour of various dishes. In essence, the closeness observed in the value of neither liked nor disliked in the experimental eggs' appearance, apparently showed that the panelists may adopt fowl egg boiling and drying as a technique to boost availability at all times. This was evidently clear as many of the panelists equally liked the taste, colour and aroma of the dried eggs, even at first exposure. This observation seemingly lent more credence to the report of USDA (2013) that described how to use liquid, frozen, and dried egg products safely.

The low proportion of the panelists who disliked the mouth feel of the control eggs, perhaps indicated their familiarity with boiled fowl eggs whereas, their dislike for dried eggs mouth feel, probably expressed their unfamiliarity with drying fowl boiled eggs. While a few of the panelists disliked the after taste of the control eggs, many liked the after taste of the dried eggs. Although many panelists liked extremely the over-all acceptability of control eggs, fair number of them equally liked the dried eggs, which apparently indicated their readiness to accept drying of fowl boiled eggs. This somewhat explained the feasibility of kiln and oven drying poultry eggs and its components, to be used as nutritive ingredients in the production of healthy food products, without adversely affecting their functional and nutritional properties (Idahor et al. 2017; Ndife et al., 2010). These findings seemed to be similar to the rating of organoleptic characteristics of local hens' eggs, offered to fairly trained panelists in Indonesia (Leke et al., 2015).
Since the proportion of the panelists that neither liked nor disliked the over-all acceptability of the experimental eggs was close, they may readily adopt drying of fowl boiled eggs, to meet the nutritional needs of pregnant women, common man and children (IEF, 2014; FAO, 2012).

The spoilt experimental eggs stored in the sales outlet within 30 days, may be largely due to the environmental conditions and partly due to the hermetically sealed fabricated egg packs used. Although all the control eggs in the kitchen spoilt, some of the kiln, solar and oven dried eggs were good or deteriorated, indicating that drying may be used to prolong the shelf life of boiled fowl eggs. Since there was no spoilage among the kiln, solar and oven dried eggs stored in the deep freezer, refrigeration could be more reliable in storing fowl boiled eggs for a relatively longer time. This observation partly corroborated several reports that fresh fowl eggs could be stored in the refrigerator and still maintain their quality for several weeks (Menezes et al., 2012; Dudusola 2009; Raji et al., 2009). Therefore, fowl eggs could be boiled, dried and refrigerated to boost the shelf life.

\section{Conclusion}

Boiling and drying resulted in fowl egg weight loss which is the required principle for effective storage, though solar drier was somewhat ineffective. The panelists were unaware of kiln, solar or oven drying of fowl eggs and claimed they have never eaten kiln, solar or oven dried fowl eggs before now. Interestingly, some of them liked the appearance, taste, colour, aroma, mouth feel, after taste and overall acceptability of the dried fowl boiled eggs. Boiling, drying and refrigeration of the fowl eggs apparently prolonged the shelf life. Therefore, these findings may serve as a viable source of information to the stakeholders and adoption of drying fowl boiled eggs may ameliorate food insecurity.

\section{Acknowledgement}

I am sincerely grateful to $\mathrm{Mr}$ Ibrahim Mohammed Adamu for the data collection and the Department of Animal Science, Nasarawa State University, Keffi, Shabu-Lafia Campus, for providing the facilities used in the study. 


\section{References}

Addo, A., Hamidu, J. A., Ansah, A. Y. and Adomako, K. (2018). Impact of egg storage duration and temperature on egg quality, fertility, hatchability and chick quality in naked neck chickens. Int J Poult Sci, 17, 175-183.

Bueschelberger, H. G. (2004). Lecithins emulsifiers in food technology. Black well publishing Ltd., Oxford, p. 1-22

Dudusola, I. O. (2009). Effects of storage methods and length of storage on some quality parameters of Japanese quail eggs. TROPICULTURA, 27(1), 45-48.

FAO, (2012) Food and Agriculture Organization of the United Nations. World Egg Day. Accessed in: http://www.fao.org/ag/againfo/home/en/news archive/2012 World Egg Day 2012.html on March 12, 2019.

Feddern, V., De Prá, M. C. Mores, R., Nicoloso, R. S., Coldebella, A. and De Abreu, P. G. (2017). Egg quality assessment at different storage conditions, seasons and laying hen strains. Ciência e Agrotecnologia, 41(3), 322$333 . \quad$ http://dx.doi.org/10.1590/141370542017413002317.

Frazier, W. C. and Westerhoff, D. C. (1988). Microbiology .2nd ed. McGraw- Hill polisher Inc., New Delhi, India.

Froning, G. W. (1998). Recent advances in egg products research and development. A paper presented at Egg Processing Workshop held at the University of California, Riverside and Modisto.

Hoffman, J. R. and Falvo, M. J. (2004). Protein rating - which is best? J. Sci. Med. 3: 118 130.

Hussein, A. S., Cantor, A. H., Pescatore, A. J and Johnson, T. H. (1996). Effect of dietary protein and energy levels on pullet development, Poultry Science, 75 (8):973-978.

Iannotti, L. L., Lutter, C. K., Bunn, D. A. and Stewart, C. P. (2014) Eggs: the uncracked potential for improving maternal and young child nutrition among the world's poor.
Nutrition Reviews, 72: 355-368. http://dx.doi.org/10.1111/nure.12107.

Idahor, K. O., Matthew, B. O., Adgidzi, E. A. , Isah, N. ,Osaiyuwu, O. H. and Sokunbi, O. A. (2017). Effects of fertilization and boiling duration on nutritional compositions and organoleptic properties of Shika-brown eggs. Proc. $42^{\text {nd }}$ Conf. Nig. Soc. for Anim. Prod. Landmark University, Omu-Aran, Nigeria, Pp $267-270$.

IEF, (2014). New international egg foundation launched to help combat malnutrition in developing countries. Accessed in: https://www.internationalegg.com/corporate/n ews/details.asp?nid=924 on October 4, 2020.

IsoNova, (2016). Biological value of eggs. IsoNova Technologies LLC. Accessed on: http://www.isonovatech.com/biological-valueof-eggs/ in October, 2016.

Jay, M. J. (2000). Modern Food Microbiology. 6th ed. Aspen Publishers Inc., Gaithersburg, Maryland.

Jin, Y. H., Lee, K.T., Lee, W. I. and Han, Y. K. (2011). Effects of storage temperature and time on the quality of eggs from laying hens at peak production. Asian-Aust J Anim Sci 24(2), 279-284. www.ajas.info.

Khan, M. J. A., Khan, S. H., Bukhsh, A., Abbass M. I. and Javed M. (2013). Effect of different storage period on egg weight, internal egg quality and hatchability characteristics of Fayuomi eggs. Ital J Anim Sci, 12(2) e51, https://doi.org/10.4081/ijas.2013.e51.

King-ori, A. M (2012). Uses of pantry Eggs and EGG yolk. Research Journal of poultry Sciences, 5(2); 9-13.

Leke, J. R., Achmanu, Sjofjan O., Najoan, M. and Mandey, J. S. (2015). Organoleptic characteristics of eggs laid by local hens fed skipjack fish waste as a source of omega -3 fatty acids in the diets acids in the diets acids in the diets acids in the diets acids in the diets. Livestock Research for Rural Development 27 (11) 2015.

Menezes, P. C., Lima, E. R., Medeiros, J. P., Oliveira, W. N. K. and Evêncio-Neto, J. (2012). 
Egg quality of laying hens in different conditions of storage, ages and housing densities. R Bras Zootec, 41(9), 2064-2069.

Miranda, J.M., Anton, X., Redondo-Valbuena, C., Roca-Saavedra, P., Rodriguez, J.A., Lamas, A., Franco, C.M. and Cepeda, A. (2015) Egg and Egg-Derived Foods: Effects on Human Health and Use as Functional Foods. Nutrients, 7:

706-729.

http://dx.doi.org/10.3390/nu7010706.

Ndife, J., Udobi, C. E. and Amaechi, N. C. (2010). Effect of oven drying on the functional and nutritional properties of whole egg and its components. African Journal of Food Science, 4(5): 254- $257 . \quad$ Accessed in: http://www.academicjournals.org/ajfs on October 25, 2020.

NIMET, (2011). Nigeria Metrological Agencies, Synoptic Office, Lafia, Nasarawa State, Nigeria.

Potter, N. and Hotchkiss, J. (2006). Food Science. 5th (Ed). CBS Publisher and Distributors, Delhi, India.

Raichlen, S. (2010). Planet Barbecue! 309 Recipes, 60 Countries. Workman Publishing. ISBN $0761148019 . \quad$ Accessed in: https://en.wikipedia.org/w/index.php?title $=\mathrm{Sm}$ oked egg\&oldid=962983231 on May 20, 2020

Raji, A. O., Aliyu, J., Igwebuike. J. U. and Chiroma, S. (2009). Effect of storage methods and time on egg quality traits of laying hens in a hot dry climate. J Agric Biol Sci 4(4), 1-7. www.arpnjournals.com.

Ruxton, C. (2013). Value of eggs during pregnancy and early childhood. Nursing Standard, 27: 41-50. Accessed in: http://dx.doi.org/10.7748/ns2013.02.27.24.41. e7343 on May 2, 2020.

SPSS, (2010). Statistical package for Social Sciences, SPSS Inc., 444. Michigan Avenue, Chicago, IL 60611.

Suresh, P. V., Rathina, R. K., Nidheesh, T., Pal, G. K. and Sakhare P. Z. (2015). Application of chitosan for improvement of quality and shelf life of table eggs under tropical room conditions. J Food Sci Technol 52(10), 63456354.
USDA, (2000). Egg Grading Manual. USDA. AA Grade. US Department of Agriculture, Washington DC.

USDA, (2013) Egg Products and Food Safety: How to Use Liquid, Frozen, and Dried Egg Products Safely. Accessed in: http://www.fsis.usda.gov/wps/portal/fsis/topic s/food-safety-education/get-answers/foodsafety-fact-sheets/egg-productspreparation/egg-products-and-foodsafety/ct index on October 20, 2020.

USDA, (2014). Sizing of eggs. United States Department of Agriculture, USDA, Food Safety and Inspection Service. Accessed in: https://en.wikipedia.org/w/index.php?title $=$ Chi cken egg sizes\&oldid $=944280360$ on April 17, 2020

Vaclavik, A. V. and Christain, W. E. (2008). Essentials of food science. Springer Science Business Media, LLC, New York. Pp. 205-230.

Wichchukit, S. and O'Mahony, M. (2014). Review. The 9-point hedonic scale and hedonic ranking in food science: some reappraisals and alternatives. J. Sci Food Agric. https://docs.ufpr.br/ aanjos//Sensometria/arti gos/04 hedonica alternativa.pdf. DOI 10.1002/jsfa.6993.

Wikipedia, (2016a). Egg as food. Accessed in: https://en.wikipedia.org/wiki/Eggasfood on November 10, 2016.

Wikipedia, (2016b). Composition of chicken egg. Accessed in: https://en.wikipedia.org/wiki/Yolk on November 20, 2016.

Zaheer, K. (2015). An updated review on chicken eggs: production, consumption, management aspects and nutritional benefits to human health. Food and Nutrition Sciences, 6: 1208-1220. Accessed in: http://dx.doi.org/10.4236/fns.2015.613127 http://www.scirp.org/journal/fns on October 22,2020 